\title{
Comatricha ellae, nomen novum (Myxomycetes)
}

\section{MARJA HÄRKÖNEN}

HÄRKÖNEN, M. 1978: Comatricha ellae, nomen novum (Myxomycetes). Karstenia 18: 23

Comatricha ellae Härkönen, nom. nov. is introduced for C. nannengae Härkönen 1977, non Lakhanpal \& Mukerji 1977.

Marja Härkönen, Department of Botany, University of Helsinki, Unioninkatu 44, SF-00170 Helsinki 17, Finland

Comatricha ellae Härkönen nom. nov.

Synonym: Comatricha nannengae Härkönen, Karstenia 17: 87 (1977), non C. nannengiae Lakhanpal \& Mukerji, Trans. Mycol. Soc. Japan 18: 127 (1977).

A new species of Myxomycetes, Comatricha nannengae Härkönen (Härkönen 1977), was named after Dr. N. Ella Nannenga-Bremekamp, a distinguished investigator of Myxomycetes. While the description was in press, Lakhanpal \& Mukerji (1977) published another taxon with almost the same name, Comatricha nannengiae Lakhanpal \& Mukerji (in the same article also spelled as 'nannegiae', 'nannengae' and 'nannengii'). The spellings 'nannengiae' and 'nannengae' are regarded as orthographic variants and therefore $C$. nannengae Härkönen is a later homonym and must be rejected. A new name, $C$. ellae, is here introduced for the species.

\section{References}

Härkönen, M. 1977: Comatricha nannengae, a new species of Myxomýcetes. - Karstenia 17: 87-89.

Lakhanpal, T. \& Mukerji, K. 1977: Taxonomic studies on Indian Myxomycetes 12. Two new species of Comatricha. - Trans. Mycol. Soc. Japan 18: 125-128.

Accepted for publication

on December 1, 1977 